Published in final edited form as:

Thromb Res. 2012 October ; 130(0 1): . doi:10.1016/j.thromres.2012.08.285.

\title{
Tissue factor and cancer
}

\author{
Wolfram Ruf \\ Department of Immunology and Microbial Science, The Scripps Research Institute, La Jolla, CA
}

\section{Summary}

The hemostatic system is involved in multiple interactions with transformed cells that progress from a dormant, non-vascularized tumor to highly metastatic phenotypes. Oncogenic transformations up regulate not only the initiator of the coagulation cascade, tissue factor (TF), but also induce other molecules that are required for TF's direct cell signaling activity, including the protease activated receptor (PAR) 2 and factor VIIa. TF-dependent signaling is a major driver for primary tumor progression, whereas TF-initiated coagulation and other components of the hemostatic system support metastasis. Basic research continues to identify pivotal molecular interactions in these processes and provides potential leads for targeting specific tumor promoting pathways associated with hemostasis and thrombosis.

\section{Introduction}

A prothrombotic state is one of the hallmarks of malignancy and cancer-associated thrombosis is a major contributor to morbidity and mortality in patients with advanced cancers (1). Tissue factor (TF), the cellular initiator of the coagulation cascade, triggers remote thrombotic complications involving procoagulant $\mathrm{TF}^{+}$microparticles shed form tumor cells (2), while other procoagulants stimulate platelet- and neutrophil-dependent thrombotic events (3; 4). TF is responsible for local thrombin generation and fibrin deposition in the tumor microenvironment and thereby influences multiple cellular interactions of tumor and host cells (5). An expanding body of literature furthermore points to important roles of direct, TF-mediated cell signaling in promoting tumor growth and angiogenesis involving the TF cytoplasmic domain coupled to proteolytic activation of the protease activated receptor (PAR) 2 or non-proteolytic integrin ligation (6-11). In addition, tumor cell TF procoagulant activity is crucial for successful metastatic tumor dissemination $(12 ; 13)$ and metastasis is significantly influenced by mutations and pharmacological interventions that induce a prothrombotic states in animal models. This brief summary reviews recent developments concerning roles of the hemostatic system in tumor progression.

\section{A crucial role for direct TF signaling in tumor cell-induced angiogenesis}

Overexpression of TF promotes primary tumor growth $(11 ; 14-16)$ and oncogenic growth factor receptors can upregulate the entire complement of the upstream TF signaling complex consisting of TF, VIIa, PAR1 and PAR2 (17). The TF-VIIa complex activates tumor cell

\footnotetext{
(c) 2012 Elsevier Ltd. All rights reserved.

Correspondence to: Wolfram Ruf, M.D., Department of Immunology and Microbial Science, SP258, The Scripps Research Institute, 10550 North Torrey Pines Road, La Jolla, CA 92037, Tel: 858-784-2748, FAX: 858-784-8480, ruf@ scripps.edu.

Publisher's Disclaimer: This is a PDF file of an unedited manuscript that has been accepted for publication. As a service to our customers we are providing this early version of the manuscript. The manuscript will undergo copyediting, typesetting, and review of the resulting proof before it is published in its final citable form. Please note that during the production process errors may be discovered which could affect the content, and all legal disclaimers that apply to the journal pertain.
} 
PAR2 to influence important aspects of tumor progression, including survival, immune modulation and angiogenesis. The molecular pathways of constitutive and hypoxia-induced extrahepatic synthesis of FVIIa have been defined in considerable detail and identified a central role for the hypoxia induced factor (HIF) $2 a$ in the tumor cell autonomous synthesis of VIIa (18-20). Hypoxia-induced TF-VIIa-PAR2 signaling appears to be particularly important for glioblastoma progression (21-23). Glioblastoma cells furthermore release $\mathrm{TF}^{+}$ micro particles that elicit TF-VIIa signaling in trans by targeting PAR2 expressed by hypoxic endothelial cells (24), inducing specifically heparin binding epidermal growth factor (HB-EGF) that activates the MET receptor, previously shown to promote a prothrombotic state (25).

Breast cancer progression is also highly dependent on TF-VIIa-PAR2 signaling. TF-VIIaPAR2 $\mathrm{G}$ protein-coupled receptor signaling induces pro-angiogenic factors, such as IL-8, CXCL1, or VEGF $(8 ; 26-28)$ as well as growth factors for myeloid cells and macrophages (27). In clinical breast cancer biopsies, upregulation of PAR2 and TF was associated with a marked phosphorylation of the TF cytoplasmic domain (29) and only patients with phosphorylated TF had a cancer relapse in this small prospective study. The polyoma middle $\mathrm{T}$ (PyMT) oncogene-driven model of spontaneous breast cancer development mimics important aspects of human tumor progression and is dependent on the angiogenic switch regulated by components of the immune system (30). PAR2-deficiency results in delayed PyMT tumor development, low levels of the chemokine CXCL1 (KC) in the tumor stroma, and reduced counts of F4/80 positive macrophages in early tumors compared to wild-type mice (9). In this model, PAR2 signaling is required for tumor cell TF cytoplasmic domain phosphorylation in vivo (29) and, importantly, deletion of the TF cytoplasmic domain delayed tumor progression similar to PAR2-deficiency (6). Late stage tumors of TF cytoplasmic domain-deleted mice also displayed altered vessel architecture and reduced macrophage numbers in the tumor stroma (6). These genetic studies suggest the novel concept that TF with its cytoplamic domain and PAR2 act together to promote proangiogenic and immune modulatory effects in tumor progression.

Proof of principle pharmacological inhibition experiments in xenograft models further substantiated the crucial role of tumor cell TF-VIIa-PAR2 signaling in tumor growth of breast cancer (8) and glioblastoma (22). These experiments were enabled by identification of a monoclonal antibody (10H10), which has no appreciable anticoagulant activity, but specifically inhibits TF-VIIa mediated PAR2 signaling (31), reduces pro-angiogenic IL-8 induction in breast cancer cells, and inhibits tumor growth and vessel density when coinjected during tumor inoculation into the orthotopic tumor microenvironment (8). These data confirmed that tumor cell TF-VIIa-PAR2 signaling is crucial for angiogenesis and suggested potential utility of targeting tumor cell pro-angiogenic signaling as an adjuvant cancer therapy.

TF also promotes angiogenesis independent of proteolytic cell signaling through a splice isoform, termed alternatively spliced TF (asTF). The alternative splicing event deletes exon 5 and thus eliminates substrate factor $\mathrm{X}$ binding and coagulant activity, but creates an alternative translation for the TF carboxyl terminus that renders asTF a soluble and secreted molecule. A binding site for integrins av $\beta 3$ and $\beta 1$ integrin heterodimers (32) is shared between full-length and as TF. asTF ligates integrins a6 $\beta 1$ and avp3 to regulate endothelial cell migration, tube formation, and sprouting and has tumor promoting activities in vivo (7; 10). In addition, asTF regulates endothelial cell function and induces leukocyte recruitment through the upregulation of adhesion receptors $(33 ; 34)$. It will be of interest to further define the relative contributions of full-length and asTF in regulating angiogenesis, immune cell function, and tumor progression in appropriate animal models in vivo. 


\section{Hematogenous metastasis depending on TF procoagulant function is modulated by a prothrombotic state}

TF-initiated thrombin generation improves metastatic tumor cell homing and survival (12; $35)$ through fibrin formation and increased adhesion $(36 ; 37)$, and platelet-dependent protection of tumor cells from natural killer cell attack (38-40). The platelet thrombin receptors glycoprotein (GP) Iba (41) and PAR4 (40) have been identified as thrombin targets in the metastatic process. In addition, the thrombin receptor PAR1 expressed by melanoma cells contributes to experimental metastasis (42-44), but spontaneous metastasis in oncogene-induced breast cancer in mice was not dependent on PAR1 (9), possibly indicating tumor-specific contributions of PAR1 to tumor progression.

Platelet-tumor cell interactions are an essential part of successful metastasis. Locally, platelets stimulate tumor growth and influence angiogenesis by releasing a variety of growth factors and chemokines stored in their granules $(45 ; 46)$. Platelets also play a pivotal role in early stages of metastasis in which activated platelets release large amounts of TGF $\beta$ that triggers TGF $\beta /$ Smad and NF- $\kappa \mathrm{B}$ signaling pathways to promote epithelial to mesenchymal transition of cancer cells (47). The recruitment of platelets by tumor cells is increasingly recognized to initiate broad multicellular interactions within the metastatic niche. The aggregates of activated platelets and tumor cells lodged at the endothelium recruit leukocytes through tethering and adhesion events typically employed in inflammation. These interactions involve selectins, integrins, platelet receptors, and soluble and extracellular matrix proteins.

Experimental metastasis is significantly reduced in mice lacking P- or L-selectin (48; 49). Tumor cells express P-selectin glycoprotein (PSGL)-1 serves as counterligands for leukocyte selectins and together with mucins and CD44 tumor cell-platelet aggregates can trigger clot formation (3). Selectin-mediated platelet and leukocyte recruitment to tumor cells activates endothelial cells to release the C-C motif chemokine 5 (CCL5), which attracts monocytes to support metastasis (49). The important role of leukocyte recruitment to sites of metastasis is further demonstrated by the pro-metastatic effect of the chemokine CCL2 (MCP-1) that is synthesized by either stromal or tumor cells. CCL2 recruits inflammatory monocytes, which express the chemokine CCL2 receptor CCR2, as well as macrophages locally at sites of metastasizing tumor cells (50). These studies elucidated that tumor cellinitiated formation of micro-thrombi supports complex heterotypic cellular interactions contributing to successful metastatic tumor cell dissemination.

While the role of local or systemic coagulation activation in cancer is an important cause for cancer-associated thrombosis, an unexpected priming of metastatic niches by tumor-initiated coagulation was recently documented. Platelet thrombi recruit transiently monocyte and macrophage populations that are crucial for successful metastasis to the lung (51).

Remarkably, in tumor bearing mice lung macrophages were expanded by tumor-derived thrombin and this priming markedly enhanced the metastatic success of injected tumor cells. Thus, the tumor induced prothrombotic state has an influence on the metastatic process. Additional experiments in clinically relevant prothrombotic animal models further expand the concept that the hemostatic system directly supports metastatic tumor progression.

Thrombin not only promotes clot formation, but is also crucial for the anticoagulant pathway upon binding to endothelial cell-expressed thrombomodulin (TM). TM-thrombin activates protein $\mathrm{C}$ (PC) in a process that is facilitated by binding of $\mathrm{PC}$ to the endothelial protein $\mathrm{C}$ receptor (EPCR). The anticoagulant system, specifically TM, PC, and EPCR, impair tumor metastasis (52-54). TM mutant mice $\left(\mathrm{TM}^{\mathrm{Pro}}\right)$ have a single amino acid substitution (Glu ${ }^{404 /}$ Pro) and exhibit $\sim 1000$-fold decreased PC activation and $\sim 100$-fold reduced binding affinity 
for thrombin (55). The resulting combined loss of local thrombin neutralization and diminished aPC generation models functional thrombomodulin deficiency that is clinically encountered under inflammatory conditions. $\mathrm{TM}^{\mathrm{Pro}}$ mice display dramatically increased metastasis that is dependent on tumor cell TF, circulating prothrombin, as well as platelets (52).

Diminished activation of the anticoagulant pathway may contribute to the enhanced

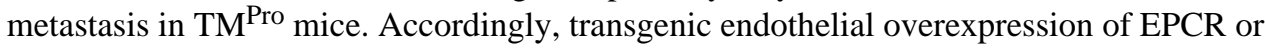
treatment with activated PC markedly reduce experimental metastasis in livers and lungs (54). Conversely, inhibition of endogenous PC increases metastasis (53). Consistent with local anticoagulant control of tumor-cell generated thrombin, mice carrying the activated PC-resistant factor $\mathrm{V}_{\text {Leiden }}$ mutation show increased hematogenous metastasis (56). Taken together, these studies suggest that thrombin neutralization by the endothelium and/or local aPC generation counteract tumor cell prometastatic ability, but the downstream targets of thrombin are incompletely defined.

\section{Perspective}

We have learned a great deal about the functions of the coagulation cascade, platelets and the fibrinolytic system in tumor progression and metastasis. However, new interactions are continuously emerging that shed light on novel molecular mechanisms that are employed by tumor cells to exploit functions of the hemostatic system. Emerging data show that EPCR is expressed by tumor cells (57-59) and contributes to survival of lung cancer metastases (60). I expect that further characterization of basic mechanisms and preclinical mouse models will continue to provide insights into potentially successful therapeutic avenues suitable to interrupt prometastatic and tumor promoting mechanisms of the coagulation cascade and its cellular receptors.

\section{Acknowledgments}

The studies described in this review were supported by NIH grant HL-60742.

\section{References}

1. Ten Cate H, Falanga A. Overview of the postulated mechanisms linking cancer and thrombosis. Pathophysiol Haemost Thromb. 2007; 36:122-130. [PubMed: 19176985]

2. Khorana AA, Ahrendt SA, Ryan CK, Francis CW, Hruban RH, Hu YC, et al. Tissue factor expression, angiogenesis, and thrombosis in pancreatic cancer. Clin Cancer Res. 2007 May 15; 13(10):2870-2875. [PubMed: 17504985]

3. Shao B, Wahrenbrock MG, Yao L, David T, Coughlin SR, Xia L, et al. Carcinoma mucins trigger reciprocal activation of platelets and neutrophils in a murine model of Trousseau syndrome. Blood. 2011 Aug 22; 118(15):4015-4023. [PubMed: 21860019]

4. Varki A. Trousseau's syndrome: multiple definitions and multiple mechanisms. Blood. 2007 Sep 15; 110(6):1723-1729. [PubMed: 17496204]

5. Ruf W, Mueller BM. Thrombin generation and the pathogenesis of cancer. Semin Thromb Hemost. 2006 Apr; 32(Suppl 1):61-68. [PubMed: 16673267]

6. Schaffner F, Versteeg HH, Schillert A, Yokota N, Petersen LC, Mueller BM, et al. Cooperation of tissue factor cytoplasmic domain and PAR2 signaling in breast cancer development. Blood. 2010 Dec 23; 116(26):6106-6113. [PubMed: 20861457]

7. van den Berg YW, van den Hengel LG, Myers HR, Ayachi O, Jordanova E, Ruf W, et al. Alternatively spliced tissue factor induces angiogenesis through integrin ligation. Proc Natl Acad Sci U S A. 2009 Nov 17; 106(46):19497-19502. [PubMed: 19875693] 
8. Versteeg HH, Schaffner F, Kerver M, Petersen HH, Ahamed J, Felding-Habermann B, et al. Inhibition of tissue factor signaling suppresses tumor growth. Blood. 2008; 111(1):190-199. [PubMed: 17901245]

9. Versteeg HH, Schaffner F, Kerver M, Ellies LG, Andrade-Gordon P, Mueller BM, et al. Protease activated receptor (PAR)2, but not PAR1 signaling promotes the development of mammary adenocarcinoma in PyMT mice. Cancer Res. 2008; 68(17):7219-7227. [PubMed: 18757438]

10. Signaevsky M, Hobbs J, Doll J, Liu N, Soff GA. Role of alternatively spliced tissue factor in pancreatic cancer growth and angiogenesis. Semin Thromb Hemost. 2008 Mar; 34(2):161-169. [PubMed: 18645921]

11. Zhang Y, Deng Y, Luther T, Müller M, Ziegler R, Waldherr R, et al. Tissue factor controls the balance of angiogenic and antiangiogenic properties of tumor cells in mice. J Clin Invest. 1994; 94:1320-1327. [PubMed: 7521887]

12. Mueller BM, Ruf W. Requirement for binding of catalytically active factor VIIa in tissue factor dependent experimental metastasis. J Clin Invest. 1998; 101(7):1372-1378. [PubMed: 9525979]

13. Palumbo JS, Talmage KE, Massari JV, La Jeunesse CM, Flick MJ, Kombrinck KW, et al. Tumor cell-associated tissue factor and circulating hemostatic factors cooperate to increase metastatic potential through natural killer cell-dependent and -independent mechanisms. Blood. 2007 Mar 19.110:133-141. [PubMed: 17371949]

14. Yu JL, May L, Lhotak V, Shahrzad S, Shirasawa S, Weitz JI, et al. Oncogenic events regulate tissue factor expression in colorectal cancer cells: implications for tumor progression and angiogenesis. Blood. 2005 Feb 15; 105(4):1734-1741. [PubMed: 15494427]

15. Kakkar AK, Chinswangwatanakul V, Lemoine NR, Tebbutt S, Williamson RCN. Role of tissue factor expression on tumour cell invasion and growth of experimental pancreatic adenocarcinoma. Br J Surg. 1999; 86:890-894. [PubMed: 10417560]

16. Liu Y, Jiang P, Capkova K, Xue D, Ye L, Sinha SC, et al. Tissue factor-activated coagulation cascade in the tumor microenvironment is critical for tumor progression and an effective target for therapy. Cancer Res. 2011 Oct 15; 71(20):6492-6502. [PubMed: 21880589]

17. Magnus N, Garnier D, Rak J. Oncogenic epidermal growth factor receptor up-regulates multiple elements of the tissue factor signaling pathway in human glioma cells. Blood. 2010 Aug 5; 116(5): 815-818. [PubMed: 20462964]

18. Koizume S, Jin M-S, Miyagi E, Hirahara F, Nakamura Y, Piao J-H, et al. Activation of cancer cell migration and invasion by ectopic synthesis of coagulation factor VII. Cancer Res. 2006 Oct 16; 66(19):9453-9460. [PubMed: 17018600]

19. Koizume S, Yokota N, Miyagi E, Hirahara F, Nakamura Y, Sakuma Y, et al. Hepatocyte nuclear factor-4-independent synthesis of coagulation factor VII in breast cancer cells and its inhibition by targeting selective histone acetyltransferases. Mol Cancer Res. 2009; 7(12):1928-1936. [PubMed: 19996301]

20. Koizume S, Ito S, Miyagi E, Hirahara F, Nakamura Y, Sakuma Y, et al. HIF2alpha-Sp1 interaction mediates a deacetylation-dependent FVII-gene activation under hypoxic conditions in ovarian cancer cells. Nucleic Acids Res. 2012 Jul 1; 40(12):5389-5401. [PubMed: 22402494]

21. Carneiro-Lobo TC, Konig S, Machado DE, Nasciutti LE, Forni MF, Francischetti IM, et al. Ixolaris, a tissue factor inhibitor, blocks primary tumor growth and angiogenesis in a glioblastoma model. J Thromb Haemost. 2009 Nov; 7(11):1855-1864. [PubMed: 19624457]

22. Gessler F, Voss V, Dutzmann S, Seifert V, Gerlach R, Kogel D. Inhibition of tissue factor/ protease-activated receptor- 2 signaling limits proliferation, migration and invasion of malignant glioma cells. Neuroscience. 2010 Feb 17; 165(4):1312-1322. [PubMed: 19958818]

23. Rong Y, Post DE, Pieper RO, Durden DL, Van Meir EG, Brat DJ. PTEN and hypoxia regulate tissue factor expression and plasma coagulation by glioblastoma. Cancer Res. 2005 Feb 15; 65(4): 1406-1413. [PubMed: 15735028]

24. Svensson KJ, Kucharzewska P, Christianson HC, Skold S, Lofstedt T, Johansson MC, et al. Hypoxia triggers a pro-angiogenic pathway involving cancer cell microvesicles and PAR-2 mediated HB-EGF signaling in endothelial cells. Proc Natl Acad Sci USA. 2011; 108:1314713152. [PubMed: 21788507] 
25. Boccaccio C, Sabatino G, Medico E, Girolami F, Follenzi A, Reato G, et al. The MET oncogene drives a genetic programme linking cancer to haemostasis. Nature. 2005 Mar 17; 434(7031):396400. [PubMed: 15772665]

26. Hjortoe GM, Petersen LC, Albrektsen T, Sorensen BB, Norby PL, Mandal SK, et al. Tissue factorfactor VIIa specific up-regulation of IL-8 expression in MDA-MB-231 cells is mediated via PAR-2 and results in increased cell migration. Blood. 2004 Jan 8; 103(8):3029-3037. [PubMed: 15070680]

27. Albrektsen T, Sorensen BB, Hjortoe GM, Fleckner J, Rao LVM, Petersen LC. Transcriptional program induced by factor VIIa-tissue factor, PAR1 and PAR2 in MDAMB-231 cells. J Thromb Haemost. 2007; 5:1588-1597. [PubMed: 17470200]

28. Liu Y, Mueller BM. Protease-activated receptor-2 regulates vascular endothelial growth factor expression in MDA-MB-231 cells via MAPK pathways. Biochem Biophys Res Commun. 2006 Jun 16; 344(4):1263-1270. [PubMed: 16650817]

29. Ryden L, Grabau D, Schaffner F, Jonsson PE, Ruf W, Belting M. Evidence for tissue factor phosphorylation and its correlation with protease activated receptor expression and the prognosis of primary breast cancer. Int J Cancer. 2010; 126(10):2330-2340. [PubMed: 19795460]

30. Lin EY, Li JF, Gnatovskiy L, Deng Y, Zhu L, Grzesik DA, et al. Macrophages regulate the angiogenic switch in a mouse model of breast cancer. Cancer Res. 2006 Dec 1; 66(23):1123811246. [PubMed: 17114237]

31. Ahamed J, Versteeg HH, Kerver M, Chen VM, Mueller BM, Hogg PJ, et al. Disulfide isomerization switches tissue factor from coagulation to cell signaling. Proc Natl Acad Sci USA. 2006; 103(38):13932-13937. [PubMed: 16959886]

32. Dorfleutner A, Hintermann E, Tarui T, Takada Y, Ruf W. Crosstalk of integrin a $3 \beta 1$ and tissue factor in cell migration. Mol Biol Cell. 2004; 15(10):4416-4425. [PubMed: 15254262]

33. Godby RC, van den Berg YW, Srinivasan RS, Sturm R, Hui DY, Konieczny SF, et al. NonProteolytic Properties of Murine Alternatively Spliced Tissue Factor: Implications for IntegrinMediated Signaling in Murine Models. Mol Med. 2012

34. Srinivasan R, Ozhegov E, van den Berg YW, Aronow BJ, Franco RS, Palascak MB, et al. Splice Variants of Tissue Factor Promote Monocyte-Endothelial Interactions by Triggering the Expression of Cell Adhesion Molecules via Integrin-Mediated Signaling. J Thromb Haemost. 2011 Aug 3.:10-7836. In Press.

35. Mueller BM, Reisfeld RA, Edgington TS, Ruf W. Expression of tissue factor by melanoma cells promotes efficient hematogenous metastasis. Proc Natl Acad Sci USA. 1992; 89(24):1183211836. [PubMed: 1465406]

36. Palumbo JS, Kombrinck KW, Drew AF, Grimes TS, Kiser JH, Degen JL, et al. Fibrinogen is an important determinant of the metastatic potential of circulating tumor cells. Blood. 2000; 96:33023309. [PubMed: 11071621]

37. Im JH, Fu W, Wang H, Bhatia SK, Hammer DA, Kowalska MA, et al. Coagulation facilitates tumor cell spreading in the pulmonary vasculature during early metastatic colony formation. Cancer Res. 2004 Dec 1; 64(23):8613-8619. [PubMed: 15574768]

38. Palumbo JS, Talmage KE, Massari JV, La Jeunesse CM, Flick MJ, Kombrinck KW, et al. Platelets and fibrin(ogen) increase metastatic potential by impeding natural killermediated elimination of tumor cells. Blood. 2004 Sep 14; 105(1):178-185. [PubMed: 15367435]

39. Nieswandt B, Hafner M, Echtenacher B, Mannel DN. Lysis of tumor cells by natural killer cells in mice is impeded by platelets. Cancer Res. 1999 Mar 15; 59(6):1295-1300. [PubMed: 10096562]

40. Camerer E, Qazi AA, Duong DN, Cornelissen I, Advincula R, Coughlin SR. Platelets, proteaseactivated receptors, and fibrinogen in hematogenous metastasis. Blood. 2004 Jul 15; 104(2):397401. [PubMed: 15031212]

41. Jain S, Zuka M, Liu J, Russell S, Dent J, Guerrero JA, et al. Platelet glycoprotein Ib alpha supports experimental lung metastasis. Proc Natl Acad Sci U S A. 2007 May 22; 104(21):9024-9028. [PubMed: 17494758]

42. Nierodzik ML, Chen K, Takeshita K, Li J-J, Huang Y-Q, Fengt X-S, et al. Proteaseactivated receptor 1 (PAR-1) is required and rate-limiting for thrombin-enhanced experimental pulmonary metastasis. Blood. 1998; 92:3694-3700. [PubMed: 9808563] 
43. Villares GJ, Zigler M, Dobroff AS, Wang H, Song R, Melnikova VO, et al. Protease activated receptor-1 inhibits the Maspin tumor-suppressor gene to determine the melanoma metastatic phenotype. Proc Natl Acad Sci U S A. 2011 Jan 11; 108(2):626-631. [PubMed: 21187389]

44. Shi X, Gangadharan B, Brass LF, Ruf W, Mueller BM. Protease-activated receptor 1 (PAR1) and PAR2 contribute to tumor cell motility and metastasis. Mol Cancer Res. 2004; 2(7):395-402. [PubMed: 15280447]

45. Gay LJ, Felding-Habermann B. Contribution of platelets to tumour metastasis. Nat Rev Cancer. 2011 Feb; 11(2):123-134. [PubMed: 21258396]

46. Sabrkhany S, Griffioen AW, oude Egbrink MG. The role of blood platelets in tumor angiogenesis. Biochim Biophys Acta. 2011 Apr; 1815(2):189-196. [PubMed: 21167916]

47. Labelle M, Begum S, Hynes RO. Direct Signaling between Platelets and Cancer Cells Induces an Epithelial-Mesenchymal-Like Transition and Promotes Metastasis. Cancer Cell. 2011 Nov 15; 20(5):576-590. [PubMed: 22094253]

48. Borsig L, Wong R, Hynes RO, Varki NM, Varki A. Synergistic effects of L- and P-selectin in facilitating tumor metastasis can involve non-mucin ligands and implicate leukocytes as enhancers of metastasis. Proc Natl Acad Sci U S A. 2002 Feb \%19; 99(4):2193-2198. [PubMed: 11854515]

49. Laubli H, Spanaus KS, Borsig L. Selectin-mediated activation of endothelial cells induces expression of CCL5 and promotes metastasis through recruitment of monocytes. Blood. 2009 Nov 12; 114(20):4583-4591. [PubMed: 19779041]

50. Qian BZ, Li J, Zhang H, Kitamura T, Zhang J, Campion LR, et al. CCL2 recruits inflammatory monocytes to facilitate breast-tumour metastasis. Nature. 2011 Jun 8; 475(7355):222-225. [PubMed: 21654748]

51. Gil-Bernabe AM, Ferjancic S, Tlalka M, Zhao L, Allen PD, Im JH, et al. Recruitment of monocytes/macrophages by tissue factor-mediated coagulation is essential for metastatic cell survival and premetastatic niche establishment in mice. Blood. 2012 Mar 29; 119(13):3164-3175. [PubMed: 22327225]

52. Horowitz NA, Blevins EA, Miller WM, Perry AR, Talmage KE, Mullins ES, et al. Thrombomodulin is a determinant of metastasis through a mechanism linked to the thrombin binding domain but not the lectin-like domain. Blood. 2011 Sep 8; 118(10):2889-2895. [PubMed: 21788337]

53. Van Sluis GL, Niers TM, Esmon CT, Tigchelaar W, Richel DJ, Buller HR, et al. Endogenous activated protein $\mathrm{C}$ limits cancer cell extravasation through sphingosine-1-phosphate receptor 1mediated vascular endothelial barrier enhancement. Blood. 2009 Aug 27; 114(9):1968-1973. [PubMed: 19571314]

54. Bezuhly M, Cullen R, Esmon CT, Morris SF, West KA, Johnston B, et al. Role of activated protein $\mathrm{C}$ and its receptor in inhibition of tumor metastasis. Blood. 2009 Apr 2; 113(14):3371-3374. [PubMed: 19188668]

55. Weiler-Guettler H, Christie PD, Beeler DL, Healy AM, Hancock WW, Rayburn H, et al. A targeted point mutation in thrombomodulin generates viable mice with a prethrombotic state. $\mathrm{J}$ Clin Invest. 1998; 101(9):1983-1991. [PubMed: 9576763]

56. Bruggemann LW, Versteeg HH, Niers TM, Reitsma PH, Spek CA. Experimental melanoma metastasis in lungs of mice with congenital coagulation disorders. J Cell Mol Med. 2008 Dec; 12(6B):2622-2627. [PubMed: 18363839]

57. Shipitsin M, Campbell LL, Argani P, Weremowicz S, Bloushtain-Qimron N, Yao J, et al. Molecular definition of breast tumor heterogeneity. Cancer Cell. 2007 Mar; 11(3):259-273. [PubMed: 17349583]

58. Hwang-Verslues WW, Kuo WH, Chang PH, Pan CC, Wang HH, Tsai ST, et al. Multiple lineages of human breast cancer stem/progenitor cells identified by profiling with stem cell markers. PLoS ONE. 2009 Dec 21.4(12):e8377. [PubMed: 20027313]

59. Beaulieu LM, Church FC. Activated protein C promotes breast cancer cell migration through interactions with EPCR and PAR-1. Exp Cell Res. 2007 Feb 15; 313(4):677-687. [PubMed: 17254565] 
60. Anton I, Molina E, Luis-Ravelo D, Zandueta C, Valencia K, Ormazabal C, et al. Receptor of Activated Protein C Promotes Metastasis and Correlates with Clinical Outcome in Lung Adenocarcinoma. Am J Respir Crit Care Med. 2012 Mar 29. 